\title{
O futebol sob a ótica das ciências sociais
}

\author{
Victor Andrade de Melo | victor.a.melo@uol.com.br
}

Foi somente a partir da transição dos anos 1970/1980 que começou a melhor se estruturar, no Brasil, um campo acadêmico ao redor do tema, destacando-se os estudos seminais de José Sérgio Leite Lopes, Simoni Lahud Guedes e Roberto Da Matta. Depois de alguns anos enfrentando certo preconceito no âmbito universitário, já se pode dizer que o assunto está consolidado e reconhecido como relevante para entender a sociedade brasileira. A atual produção pujante é um dos indicadores mais visíveis do importante conjunto de iniciativas entabuladas pelos pesquisadores que se debruçam sobre o futebol. Já temos até "clássicos", livros de referência muito lidos e citados, embora também criticados em função do esperado avanço nos debates. Victor Andrade de Melo (professor da UFRJ) indica livros mais recentes que abordam a modalidade desde os olhares das ciências sociais. Essas sugestões são um pequeno exemplo da riqueza de abordagens sobre nosso mais popular esporte.
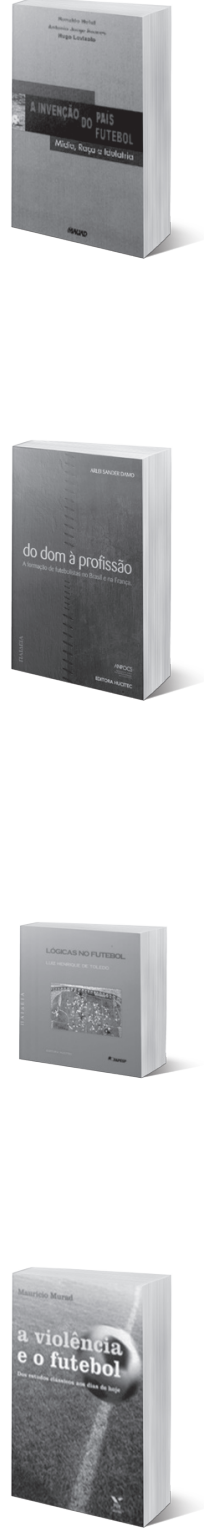

\section{A VIOLÊNCIA E 0 FUTEBOL: Dos estudos clássicos aos dias de hoje Mauricio Murad. Rio de Janeiro: FGV, 2007.}

Uma das facetas mais espetaculares do futebol é a participação dos torcedores, sem dúvida um dos elementos responsáveis por fazer do esporte um fenômeno planetário e tão importante. Nos últimos anos, todavia, mais do que nas décadas anteriores, cenas de violência nos estádios têm colocado em xeque a sua existência. O livro de Maurício Murad, um dos pioneiros nos estudos do futebol no Brasil, lança um olhar cuidadoso sobre o tema, procurando afastar abordagens passionais e superficiais.

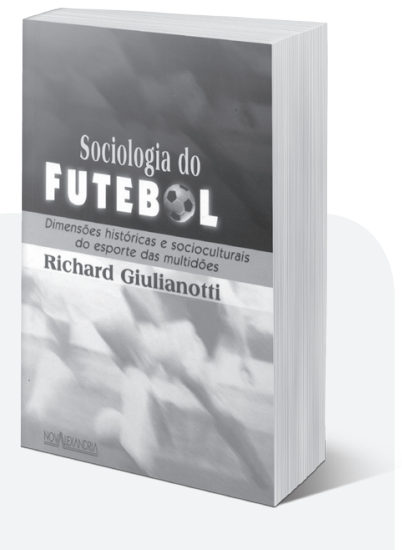

SOCIOLOGIA DO FUTEBOL: Dimensões históricas e socioculturais do esporte

Richard Giulianotti. São Paulo: Nova Alexandria, 2002.

Único livro publicado em português de um dos mais importantes pesquisadores mundiais da modalidade, a obra é um grande panorama dos principais temas abordados ao redor do futebol desde o ponto de vista das ciências sociais. Recuperando algo da sua trajetória histórica, o autor se debruça na sua interface com as noções de classe, nação, etnia, gênero, cultura, política, mercado. 